\title{
Comparison of Cell Wall Polysaccharide Composition and Structure Between Strains of Sporothrix schenckii and Sporothrix brasiliensis
}

OPEN ACCESS

Edited by:

Leonardo Nimrichter,

Federal University of Rio de Janeiro,

Brazil

Reviewed by:

Max Carlos Ramírez-Soto, Universidad Peruana Cayetano

Heredia, Peru

Javier Capilla,

University of Rovira i Virgili, Spain

${ }^{*}$ Correspondence:

Gustavo A. Niño-Vega

gustavo.nino@ugto.mx

Specialty section:

This article was submitted to

Infectious Diseases,

a section of the journal

Frontiers in Microbiology

Received: 17 June 2021

Accepted: 24 August 2021

Published: 20 September 2021

Citation:

Villalobos-Duno HL, Barreto LA, Alvarez-Aular Á, Mora-Montes HM,

Lozoya-Pérez NE, Franco $B$

Lopes-Bezerra LM and

Niño-Vega GA (2021) Comparison of Cell Wall Polysaccharide Composition

and Structure Between Strains of

Sporothrix schenckii and

Sporothrix brasiliensis.

Front. Microbiol. 12:726958.

doi: 10.3389/fmicb.2021.726958

\begin{abstract}
Héctor L. Villalobos-Duno', Laura A. Barreto², Álvaro Alvarez-Aular', Héctor M. Mora-Montes ${ }^{4}$, Nancy E. Lozoya-Pérez ${ }^{4}$, Bernardo Franco ${ }^{4}$, Leila M. Lopes-Bezerra ${ }^{5}$ and Gustavo A. Niño-Vega ${ }^{4 *}$
\end{abstract}

'Laboratorio de Micología, Centro de Microbiología y Biología Celular, Instituto Venezolano de Investigaciones Científicas, Caracas, Venezuela, ${ }^{2}$ Instituto Superior de Formación Docente Salome Ureña, Santo Domingo, Dominican Republic, ${ }^{3}$ Laboratorio de Síntesis Orgánica y Productos Naturales, Centro de Química, Instituto Venezolano de Investigaciones Cientificas, Caracas, Venezuela, ${ }^{4}$ División de Ciencias Naturales y Exactas, Departamento de Biología,

Universidad de Guanajuato, Guanajuato, Mexico, ${ }^{5}$ Biomedical Institute, University of São Paulo, São Paulo, Brazil

Sporothrix schenckii, Sporothrix brasiliensis, and Sporothrix globosa are the main causative agents of sporotrichosis, a human subcutaneous mycosis. Differences in virulence patterns are associated with each species but remain largely uncharacterized. The S. schenckii and S. brasiliensis cell wall composition and virulence are influenced by the culturing media, with little or no influence on S. globosa. By keeping constant the culturing media, we compared the cell wall composition of three S. schenckii and two S. brasiliensis strains, previously described as presenting different virulence levels on a murine model of infection. The cell wall composition of the five Sporothrix spp. strains correlated with the biochemical composition of the cell wall previously reported for the species. However, the rhamnoseto- $\beta$-glucan ratio exhibits differences among strains, with an increase in cell wall rhamnoseto- $\beta$-glucan ratio as their virulence increased. This relationship can be expressed mathematically, which could be an important tool for the determination of virulence in Sporothrix spp. Also, structural differences in rhamnomannan were found, with longer side chains present in strains with lower virulence reported for both species here studied, adding insight to the importance of this polysaccharide in the pathogenic process of these fungi.

Keywords: Sporothrix spp., fungal cell wall, beta-gucan, fungal virulence, Rhamnose, Rhamnomannan

\section{INTRODUCTION}

Sporotrichosis, a cutaneous and subcutaneous mycosis of humans and other mammals, is caused by species described within the pathogenic clade of the Sporothrix genus, of which S. brasiliensis, S. schenckii, and S. globosa are the three species of major clinical importance (de Beer et al., 2016). All species of the Sporothrix genus are thermo-dimorphic fungi, presenting 
a saprophytic sporulating mycelial phase at $25-28^{\circ} \mathrm{C}$ and a yeast-like pathogenic phase at $36-37^{\circ} \mathrm{C}$. In humans, the disease is characterized by cutaneous and subcutaneous lesions with regional lymphocutaneous dissemination, although some pulmonary and systemic infections have been reported (Callens et al., 2006). It is a neglected infectious disease with a worldwide distribution, and a higher incidence in tropical and subtropical countries (Barros et al., 2011; Chakrabarti et al., 2014). The cutaneous disease begins with a traumatic inoculation of the fungus by contaminated soil or plant debris or through bites and scratches from infected cats (Barros et al., 2011; Chakrabarti et al., 2014). Multiple infections might arise from a single source, which can lead to outbreaks (Chakrabarti et al., 2014).

Sporothrix schenckii is the most widespread species of the pathogenic clade present in the Americas, Europe, Africa, and Asia and is mainly associated with a sapronosis (Zhang et al., 2015), similarly to S. globosa, which is predominant in Asia. Furthermore, $S$. brasiliensis is an emerging species related to cat-transmitted sporotrichosis, mainly described in Brazil but now, also, present in other South American countries (Chakrabarti et al., 2014; Etchecopaz et al., 2020; Rossow et al., 2020).

Differences in the virulence profiles in experimental models of infection have been reported within the pathogenic clade. Sporothrix brasiliensis is reported as the most virulent species, followed by $S$. schenckii, and S. globosa, with the latter been reported as the species with the lowest virulence of the three (Arrillaga-Moncrieff et al., 2009; Almeida-Paes et al., 2015; Clavijo-Giraldo et al., 2016; Lozoya-Pérez et al., 2020). However, differences within S. schenckii clinical isolates have also been reported, ranging from highly virulent to non-virulent isolates (Fernandes et al., 2013; Almeida-Paes et al., 2015). Some factors, such as melanization, thermotolerance, protein secretion, and immunogenicity have been related to the differences in virulence patterns between the Sporothrix spp. and within clinical isolates (Fernandes et al., 2013; Almeida-Paes et al., 2015).

The fungal cell wall protects the fungus, acting as an initial barrier against hostile environments while preserving the cell's integrity against internal turgor pressure. It is a dynamic structure, presenting continuous changes in composition and structural organization as the cell grows or undergoes morphological changes (Latgé, 2007). These changes are strongly regulated during the cell cycle, or in response to environmental conditions, stress, and mutations in the cell wall biosynthetic processes (Klis et al., 2006; Ruiz-Herrera et al., 2006).

In general, fungal cell walls are bilayered structures, with the innermost layer comprising a core of covalently attached and branched $\beta-(1,3)$ glucan, forming intrachain hydrogen bonds with chitin assembled into fibrous microfibrils, and all together forming a scaffold around the cell (Gow et al., 2017). The $\beta$ - $(1,3)$ glucan is a highly immunogenic molecule and is one of the main fungal pathogen-associated molecular patterns (PAMP) that bind to a very specific pathogen recognition receptor (PRR) present on the surface of the host's immune cells, the C-type lectin dectin-1 (Hernández-Chávez et al., 2017). Chitin, is an important immunoreactive polysaccharide, that interacts with different PRRs in a size-dependent mechanism, where big $(70-100 \mu \mathrm{m})$ or very small $(<2 \mu \mathrm{m})$ chitin particles do not trigger immune reactions, while medium-sized chitin particles $(40-70 \mu \mathrm{m})$ induce a proinflammatory response, whereas small-sized chitin particles $(2-10 \mu \mathrm{m})$ trigger an antiinflammatory response (Hernández-Chávez et al., 2017). In general, these two polysaccharides are often masked by the components of the cell wall outer layer, which differs from the inner scaffold layer (Erwig and Gow, 2016). The S. schenckii and $S$. brasiliensis cell wall is mainly composed of structural polysaccharides, $\beta$-glucans, and chitin and has a peptiderhamnomannan (PRM) outermost layer (Lopes-Bezerra et al., 2018). More recently, it has been reported that the culture media have an influence on changes in the cell wall composition and structure, as well as on the virulence of S. schenckii and S. brasiliensis but not on S. globosa (Lozoya-Pérez et al., 2020).

Within the frame of all the previous bodies of evidence, in the present work, we examine and compare the S. schenckii and $S$. brasiliensis cell wall composition in different strains. The isolates studied here, showed distinct virulence profiles (Nascimento et al., 2008; Castro et al., 2013), and the analysis of possible differences in the composition and/or the relative content of cell wall components may add new important aspects that correlate with their difference in virulence profiles.

\section{MATERIALS AND METHODS}

\section{Strains and Growth Conditions}

Fungal strains used in this study are listed in Table 1. The yeast morphology was obtained by growing cells on Brain Heart Infusion (BHI, Oxoid, Hampshire, United Kingdom) liquid medium, with continuous shaking at $100 \mathrm{rpm}$ for 4 days at $37^{\circ} \mathrm{C}$. Cells were inspected under a phase-contrast microscope (Nikon Optiphot, Japan) before being used to check for contamination or partial differentiation.

\section{Cell Wall Fractionation}

Yeast cells from cultures in exponential phase were collected by centrifugation at $8,000 \times \mathrm{g}$ for $1 \mathrm{~h}$ at $10^{\circ} \mathrm{C}$. Briefly, the fungal pellets were suspended in distilled water with an equal volume of glass beads $(0.45-0.50 \mathrm{~mm}$ diameter) and shaken five times in a Braun homogenizer (Braun, Melsungen, Germany) for $1 \mathrm{~min}$, followed by $1 \mathrm{~min}$ cooling on ice between shakings. Cell disruption was followed by light microscopy. Cell homogenates were washed out of glass beads with distilled water and centrifuged at $480 \times g$ for $5 \mathrm{~min}$ at $4^{\circ} \mathrm{C}$. The pellet was freeze-dried, weighted, and

TABLE 1 | Strains used in this work.

\begin{tabular}{|c|c|c|c|}
\hline Organism & Strain & $\begin{array}{l}\text { Virulence } \\
\text { reported in the } \\
\text { mouse model }\end{array}$ & Reference \\
\hline S. brasiliensis & 5110 (ATCC MYA 4823) & High & Castro \\
\hline S. brasiliensis & IPEC 17943 (ATCC MYA 4824) & Low & et al., 2013 \\
\hline S. schenckii & 15,383 (ATCC MYA 4820) & Mild & \\
\hline S. schenckii & 1,099-18 (ATCC MYA 4821) & Low & \\
\hline S. schenckii & M-64 (ATCC MYA 4822) & Non-virulent & $\begin{array}{l}\text { Nascimento } \\
\text { et al., } 2008\end{array}$ \\
\hline
\end{tabular}


fractionated by alkaline separation (Previato et al., 1979; San-Blas and San-Blas, 1994; Lopes-Bezerra et al., 2018). Briefly, the freezedried material was re-suspended in $1 \mathrm{M} \mathrm{NaOH}$ for $16 \mathrm{~h}$, and the suspension was centrifuged to separate the alkali-insoluble material from the supernatant (fraction 1). The supernatant was neutralized with $1 \mathrm{~N} \mathrm{HCl}$, centrifuged and the pellet (alkali-soluble and acid-insoluble, fraction 2) separated from the supernatant (alkali and acid-soluble, fraction 3), which was further analyzed as described previously (Lopes-Bezerra et al., 2018). Rhamnomannan was obtained by treating fraction 3 with Fehling's reagent at $4^{\circ} \mathrm{C}$ as reported previously (Previato et al., 1979). The insoluble copper complexes generated, were centrifuged, washed three times with $3 \% \mathrm{KOH}$, twice with neat ethanol, and collected. The resulting residue was suspended in distilled water and cations removed with Dowex 50W-X4 $\left(\mathrm{H}^{+}\right.$form; Sigma-Aldrich, St. Louis, MO, United States) for $1 \mathrm{~h}$ at room temperature; the supernatant was precipitated by the addition of four volumes of neat ethanol. The residue was collected by centrifugation at $8,000 \times g$ for $10 \mathrm{~min}$ (fraction 4 , rhamnomannan). The mother liquor of the copper complexes was neutralized with acetic acid and centrifuged. The supernatant was dialyzed for $72 \mathrm{~h}$ against distilled water and deionized with a mixture of Dowex $1\left(\mathrm{HCO}_{3}{ }^{-}\right.$ form; Sigma-Aldrich, St. Louis, MO, United States) and Dowex $50 \mathrm{~W}-\mathrm{X} 4\left(\mathrm{H}^{+}\right.$form $)$, the filtrate was concentrated, and the polysaccharides present were precipitated by the addition of three volumes of neat ethanol (fraction 5). All fractions obtained were freeze-dried.

\section{Chemical Analyses of Cell Wall Fractions}

Sugar and total amino acid content of cell wall fractions were determined as follows: for hexose content, $10 \mathrm{mg}$ of each cell wall fraction was resuspended in $1 \mathrm{ml}$ of $1 \mathrm{M} \mathrm{HCl}$, sealed in a $2 \mathrm{ml}$ Wheaton 176,776 ampoule, and heated for $3 \mathrm{~h}$ at $100^{\circ} \mathrm{C}$. Hydrolyzed samples were diluted $1 / 10$ or 1/100. Sugar quantification was accomplished by the Anthrone method for hexose content quantification in concentrated $\mathrm{H}_{2} \mathrm{SO}_{4}$. To determine amino acid and amino sugar contents, $10 \mathrm{mg}$ of each sample was resuspended in $1 \mathrm{ml} 6 \mathrm{M} \mathrm{HCl}$, sealed in a $2 \mathrm{ml}$ Wheaton 176,776 ampoule, and heated for $16 \mathrm{~h}$ at $100^{\circ} \mathrm{C}$. Amino acid and amino sugar content were determined employing alanine and glucosamine solutions as standards, as described previously (Rondle and Morgan, 1955; Yemm et al., 1955). For rhamnose quantification, $10 \mathrm{mg}$ of fraction 3 was resuspended in $1 \mathrm{ml}$ of $1 \mathrm{M} \mathrm{HCl}$, sealed in a $2 \mathrm{ml}$ Wheaton 176,776 ampoule, and heated for $3 \mathrm{~h}$ at $100^{\circ} \mathrm{C}$. Hydrolyzed samples were diluted $1 / 10$ or $1 / 100$. Quantification of methyl pentoses was conducted (Dische and Shettles, 1948) using $85.7 \% \mathrm{H}_{2} \mathrm{SO}_{4}$ and $3 \%$ cysteine in the reaction mixtures and rhamnose to construct a standard curve.

\section{Infrared Spectroscopy}

Samples were prepared as $\mathrm{KBr}$ pellets. IR spectra were recorded from 3,500 to $500 \mathrm{~cm}^{-1}$, using a Nicolet iS10 IR spectrometer (Thermo Fisher Scientific, Waltham, MA, United States), coupled to the OMNIC 8.0 software, following the indications of the

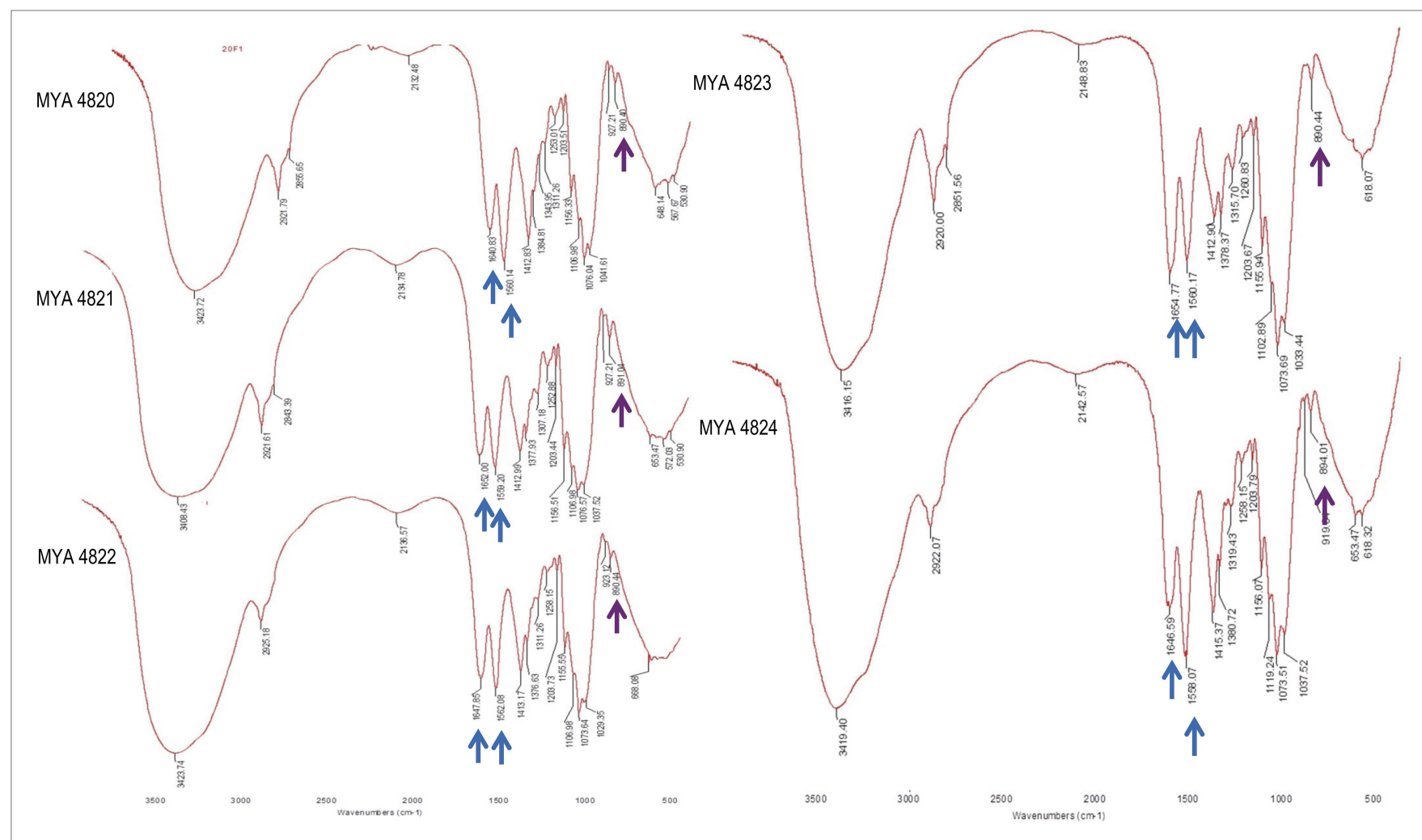

FIGURE 1 | Sporothrix schenckii strains IR spectra of alkali-insoluble polysaccharides. Here, the signals corresponding to all strains are shown. Chitin and $\beta$-glucan signals are indicated with blue and purple arrows respectively, also are present signals of $\beta$-glucans $\left(1,3\right.$ and 1,6 evidenced by peaks at 1156,1076 , and 1,041 cm $\left.{ }^{-1}\right)$. 
Infrared Spectroscopy Service, Center of Chemistry, IVIC, Caracas, Venezuela.

\section{Nuclear Magnetic Resonance Analysis}

To obtain the structural data, ${ }^{13} \mathrm{C}$ and ${ }^{1} \mathrm{H}$ NMR were employed, briefly, samples of the polysaccharide fraction to be analyzed and standards (ca. $20 \mathrm{mg}$ ) were solubilized in $\mathrm{D}_{2} \mathrm{O}$ or $2 \% \mathrm{NaOD}$ and the spectra obtained at $75 \mathrm{MHz}$ with a recollecting time of $16 \mathrm{~h}$ and $70^{\circ} \mathrm{C}$ using a Bruker 300 Ultrashield spectrometer, according to the indication of the Nuclear Magnetic Resonance Service, Center of Chemistry, IVIC, Caracas, Venezuela.

\section{Analysis of Chitin Exposure on the Cell Wall Surface Using Flow Cytometry Analysis}

For chitin exposure analysis, cells were stained with $1 \mathrm{mg} / \mathrm{ml}$ wheat germ agglutinin-fluorescein isothiocyanate (Sigma-Aldrich, St. Louis, MO, United States), for $60 \mathrm{~min}$ at room temperature. Flow cytometry was performed in a MoFlo XDP apparatus (Beckman Coulter), collecting 50,000 singlet events. Fluorescence of positive events was recovered from the compensated FL3 (green) channel using unlabeled yeast cells. Total population densities were gated and analyzed using FlowJo (version 10.0.7) software.

The heat-killed $(\mathrm{HK})$ cells were prepared by incubating at $60^{\circ} \mathrm{C}$ for $2 \mathrm{~h}$. The cellular death was confirmed by incubating aliquots of the preparations in YPD plates at $37^{\circ} \mathrm{C}$ for 5 days.

\section{Statistical Analysis}

Quantifications of cell wall components were made by triplicate. Statistical analyses were done by the Tukey Honestly Significant Difference (HSD) post hoc test. Differences were considered statistically significant at $p<0.05$.

\section{RESULTS}

\section{Cell Wall Composition and Structure of Sporothrix Strains Under Study}

Structural and chemical analyses of polysaccharides from yeast walls of S. schenckii strains MYA 4820, MYA 4821, MYA 4822,

A

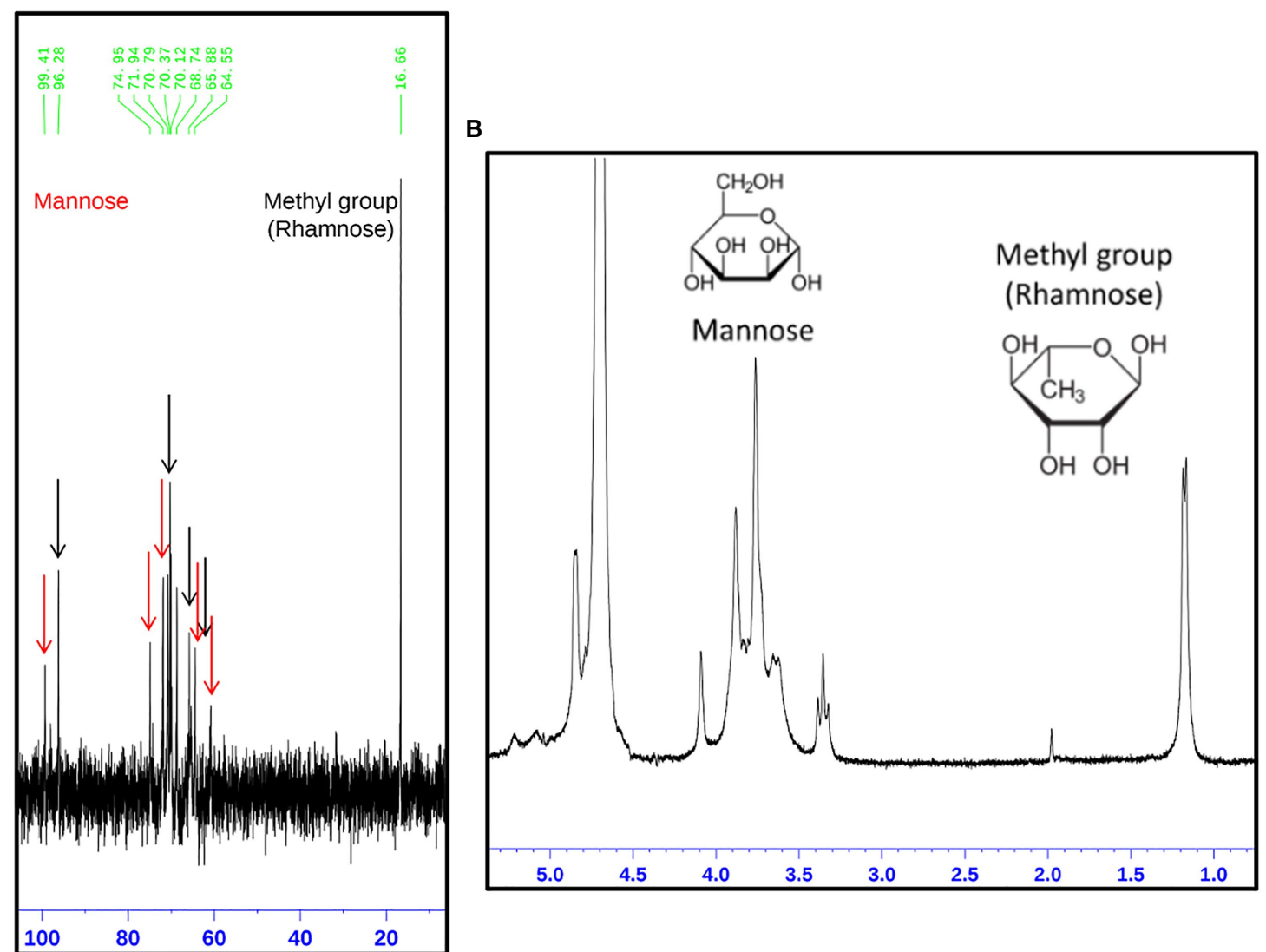

FIGURE 2 | Structural analysis of the rhamnomannan present in the Sporothrix strains employing ${ }^{13} \mathrm{C}-\mathrm{NMR}$ and ${ }^{1} \mathrm{H}-\mathrm{NMR}(\mathbf{A}, \mathbf{B}$, respectively). On the image, the spectrum corresponding to the rhamnomannan fraction of S. schenckii strain MYA 4820 is presented as a representative spectrum of both, S. schenckii and S. brasiliensis strains under study. (A) The signals corresponding to the carbon atoms in the mannose and rhamnose residues are shown as arrows, red for mannose and black for rhamnose. The corresponding signals are shown in Table 1. (B) Show the presence of the methyl group belonging to rhamnose (1.18 and 1.17 p.p.m.) and the signals correspond to the proton bound to carbon 5 next to the methylene group for carbon 6 in the mannose ring (3.32, 3.35, and 3.39p.p.m.). 
and S. brasiliensis strains MYA 4823 and MYA 4824 were analyzed (Table 1). Cell walls from BHI-grown cells were purified and fractioned by the acid and alkali solubility and insolubility methods, as previously reported for Sporothrix cell wall analyses (Previato et al., 1979; Lopes-Bezerra et al., 2018). For polysaccharide structural characterization, IR spectroscopies, as well as proton and ${ }^{13} \mathrm{C}$ nuclear magnetic resonance $\left({ }^{1} \mathrm{H}\right.$ $\mathrm{NMR}$ and ${ }^{13} \mathrm{C}$-NMR respectively) were used, and the generated spectra compared with IR, ${ }^{1} \mathrm{H}-\mathrm{NMR}$, and ${ }^{13} \mathrm{C}-\mathrm{NMR}$ spectra previously reported for S. schenckii (Travassos et al., 1973; Gorin et al., 1977; Gow et al., 1987; Lopes-Alves et al., 1992; Lopes-Bezerra et al., 2018). For the five strains analyzed, IR spectra of the alkali-insoluble cell wall fraction showed characteristic polysaccharide absorption signals (Figure 1), showing a strong and wideband around $3,400 \mathrm{~cm}^{1}$ and additional bands around 2,921, 1,641, and $1,412 \mathrm{~cm}^{-1}$ (Rodríguez-Brito et al., 2010). Absorption bands around 1,557 and $1,662 \mathrm{~cm}^{-1}$ evidenced the presence of chitin, while $\beta$-glucan is evidenced by absorption bands at around 897 and $1,378 \mathrm{~cm}^{-1}$
(Rodríguez-Brito et al., 2010). Also, the presence of absorption peaks belonging to $\beta$-(1,3)-(1,6)-glucan $(1,160,1,078$, and $1,044 \mathrm{~cm}^{-1}$; Synytsya and Novak, 2014), is present in all the IR spectra obtained from all the strains.

The rhamnomannan characterization was followed by ${ }^{1} \mathrm{H}-\mathrm{NMR}$ and ${ }^{13} \mathrm{C}-\mathrm{NMR}$. For all the cases, ${ }^{1} \mathrm{H}-\mathrm{NMR}$ spectra showed the presence of the methyl group that belongs to rhamnose (1.18$1.17 \mathrm{ppm}$ ) and the signals corresponding to the proton linked to carbon $5(3.32-4.10 \mathrm{ppm})$ next to the methylene group from carbon six in the mannose ring (Figure 2B). The $\mathrm{H} 1$ region of the ${ }^{1} \mathrm{H}-\mathrm{NMR}$ spectra for all the strains under study is shown in Figure 3, presenting proton signals 5.21-5.26, 5.08-5.13, and 4.84-4.88ppm, which are characteristic of Sporothrix rhamnomannan, as previously reported (Travassos et al., 1973, 1974). Signals 5.08-5.12 and 5.21-5.25 ppm are related to the presence of $\operatorname{Rha}(\alpha 1-4) \mathrm{GlcA}(\alpha 1,2) \mathrm{Man}(\alpha 1,2) \mathrm{Man}-\mathrm{ol}$, as previously reported (Lopes-Alves et al., 1992). Also, the presence of a proton signal $4.97 \mathrm{ppm}$ previously reported as present in S. brasiliensis strain MYA 4823 (Lopes-Bezerra et al., 2018) is

\section{${ }^{1} \mathrm{H}-\mathrm{NMR}$ spectra from $\mathrm{H} 1$ region}

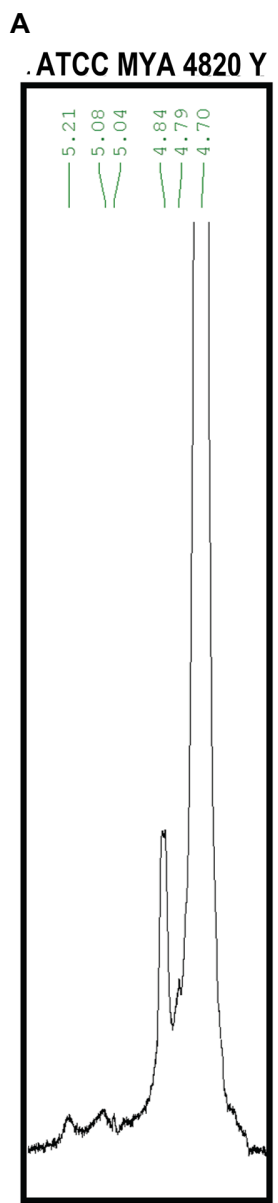

B

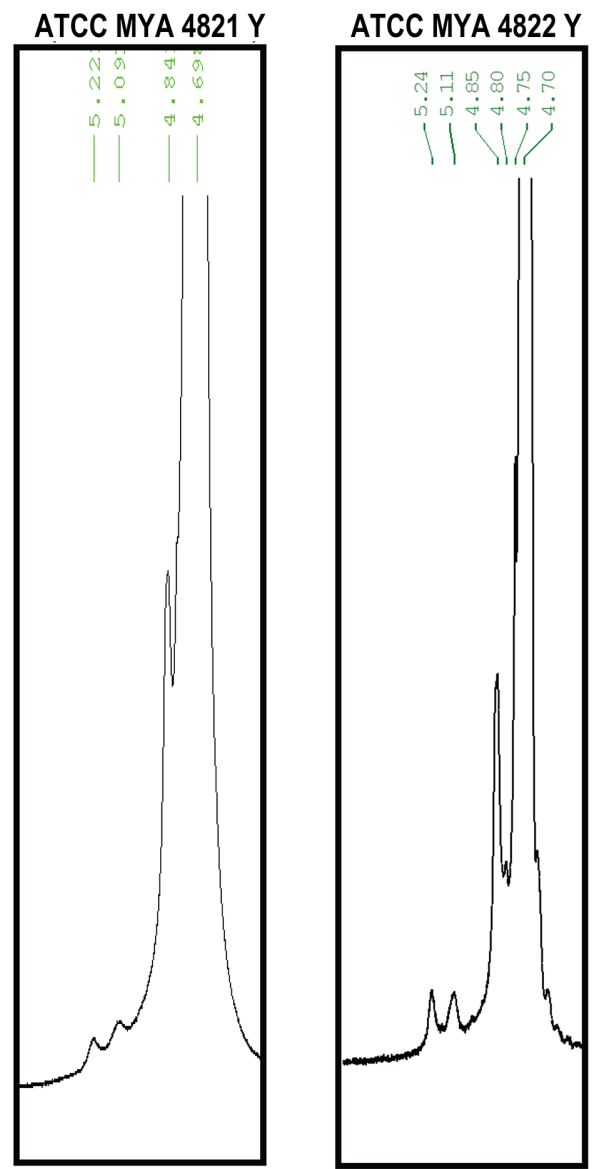

S. schenckii strains

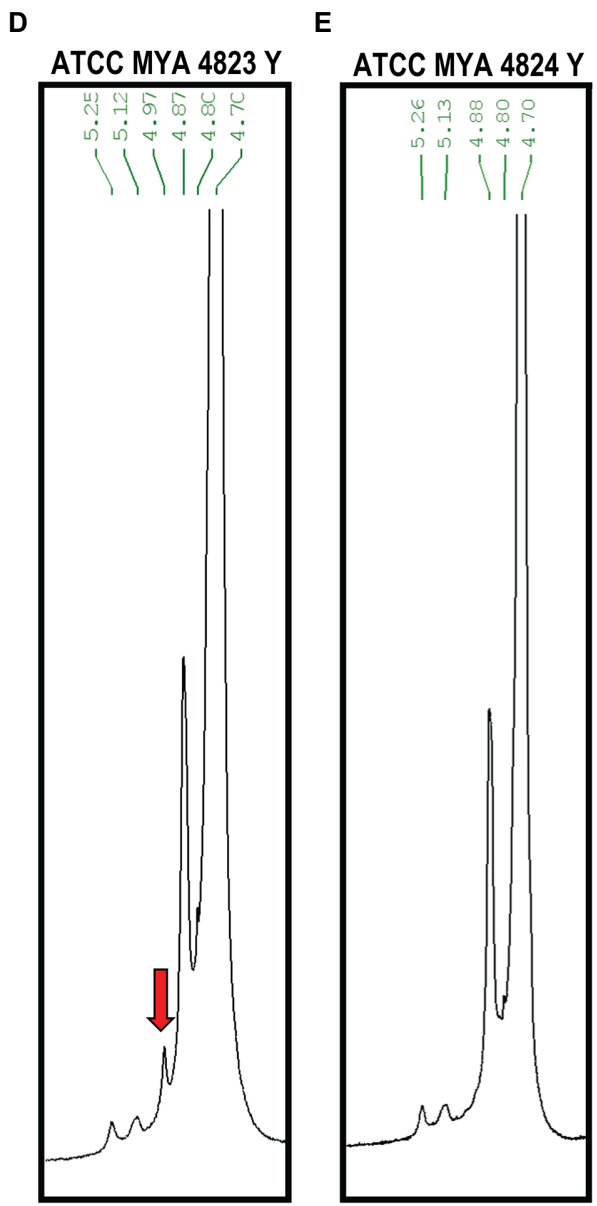

S. brasiliensis strains

FIGURE 3 | ${ }^{1} \mathrm{H}-\mathrm{NMR}$ of the rhamnomannan fraction isolated from S. schenckii and S. brasiliensis yeast cells. The H1 region of the rhamnomannans of S. schenckii (A-C) and S. brasiliensis (D,E) is enlarged. The red arrow shows a unique signal for S. brasiliensis strain 4823 as was described recently (Lopes-Bezerra et al., 2018). 
TABLE $2 \mid{ }^{13} \mathrm{C}-N M R$ signals of S. schenckii and S. brasiliensis rhamnomannan, yeast phase.

\begin{tabular}{|c|c|c|c|c|c|c|c|c|}
\hline \multirow{2}{*}{ Isolate } & \multirow{2}{*}{ Structure } & \multicolumn{7}{|c|}{${ }^{13} \mathrm{CNMR}$ - Signal, $\delta_{\mathrm{c}}\left(70^{\circ} \mathrm{C} ; \mathrm{ppm}\right)$} \\
\hline & & C1 & C2 & C3 & C4 & C5 & C6 & $\mathrm{CH}_{3}$ \\
\hline S. schenckii & $\begin{array}{l}\alpha-L-\text { Rhamnopyranose non-reducing end } \\
\text { units }\end{array}$ & 96.28 & 70.37 & N.R. & 71.94 & 68.74 & ------- & 16.7 \\
\hline MYA-4820 & $\begin{array}{l}\text { 3,6-di-O-substituted } \alpha \text {-D-mannopyranose } \\
\text { units }\end{array}$ & 99.4 & 65.88 & 74.95 & 64.55 & 70.79 & 65.40 & $-\cdots-$ \\
\hline S. schenckii & $\begin{array}{l}\alpha-L-\text { Rhamnopyranose non-reducing end } \\
\text { units }\end{array}$ & 96.28 & 70.36 & N.R. & 71.93 & 68.74 & ------ & 16.7 \\
\hline MYA-4821 & $\begin{array}{l}\text { 3,6-di-O-substituted } \alpha \text {-D-mannopyranose } \\
\text { units }\end{array}$ & 99.44 & 65.88 & 74.92 & 64.55 & 70.82 & 65.397 & ------- \\
\hline S. schenckii & $\begin{array}{l}\alpha \text {-L-Rhamnopyranose non-reducing end } \\
\text { units }\end{array}$ & N.O. & 70.13 & N.R. & 71.97 & 68.72 & ------ & 16.7 \\
\hline MYA-4822 & $\begin{array}{l}\text { 3,6-di-O-substituted } \alpha \text {-D-mannopyranose } \\
\text { units }\end{array}$ & 99.4 & 65.91 & 74.98 & 64.57 & 70.72 & 65.44 & $--\cdot--$ \\
\hline S. brasiliensis & $\begin{array}{l}\alpha \text {-L-Rhamnopyranose nonreducing end } \\
\text { units }\end{array}$ & 96.39 & 70.17 & N.R. & 72.05 & 68.8 & ------ & 16.7 \\
\hline MYA-4823 & $\begin{array}{l}\text { 3,6-di-O-substituted } \alpha \text {-D-mannopyranose } \\
\text { units }\end{array}$ & 99.54 & 66.04 & 75.08 & 64.65 & 70.92 & 65.57 & ------- \\
\hline S. brasiliensis & $\begin{array}{l}\alpha \text {-L-Rhamnopyranose non-reducing end } \\
\text { units }\end{array}$ & 96.31 & 70.11 & N.R. & 71.96 & 68.7 & ------- & 16.7 \\
\hline MYA-4824 & $\begin{array}{l}\text { 3,6-di-O-substituted } \alpha \text {-D-mannopyranose } \\
\text { units }\end{array}$ & 99.43 & 65.9 & 74.94 & 64.58 & 70.8 & 65.48 & ------- \\
\hline \multirow{2}{*}{$\begin{array}{l}\text { Gorin et al., } \\
1977\end{array}$} & $\begin{array}{l}\alpha \text {-L-Rhamnopyranose non-reducing end } \\
\text { units }\end{array}$ & 98.3 & $72-71.9$ & N.R. & 73.6 & 70.8 & ------- & 18.4 \\
\hline & $\begin{array}{l}\text { 3,6-di-O-substituted } \alpha \text {-D-mannopyranose } \\
\text { units }\end{array}$ & 101.1 & 67.6 & 76.6 & 66.3 & 72.4 & 67.3 & ------ \\
\hline
\end{tabular}

N.O., not observed; N.R., no registered. Bold values correspond to values previously reported.
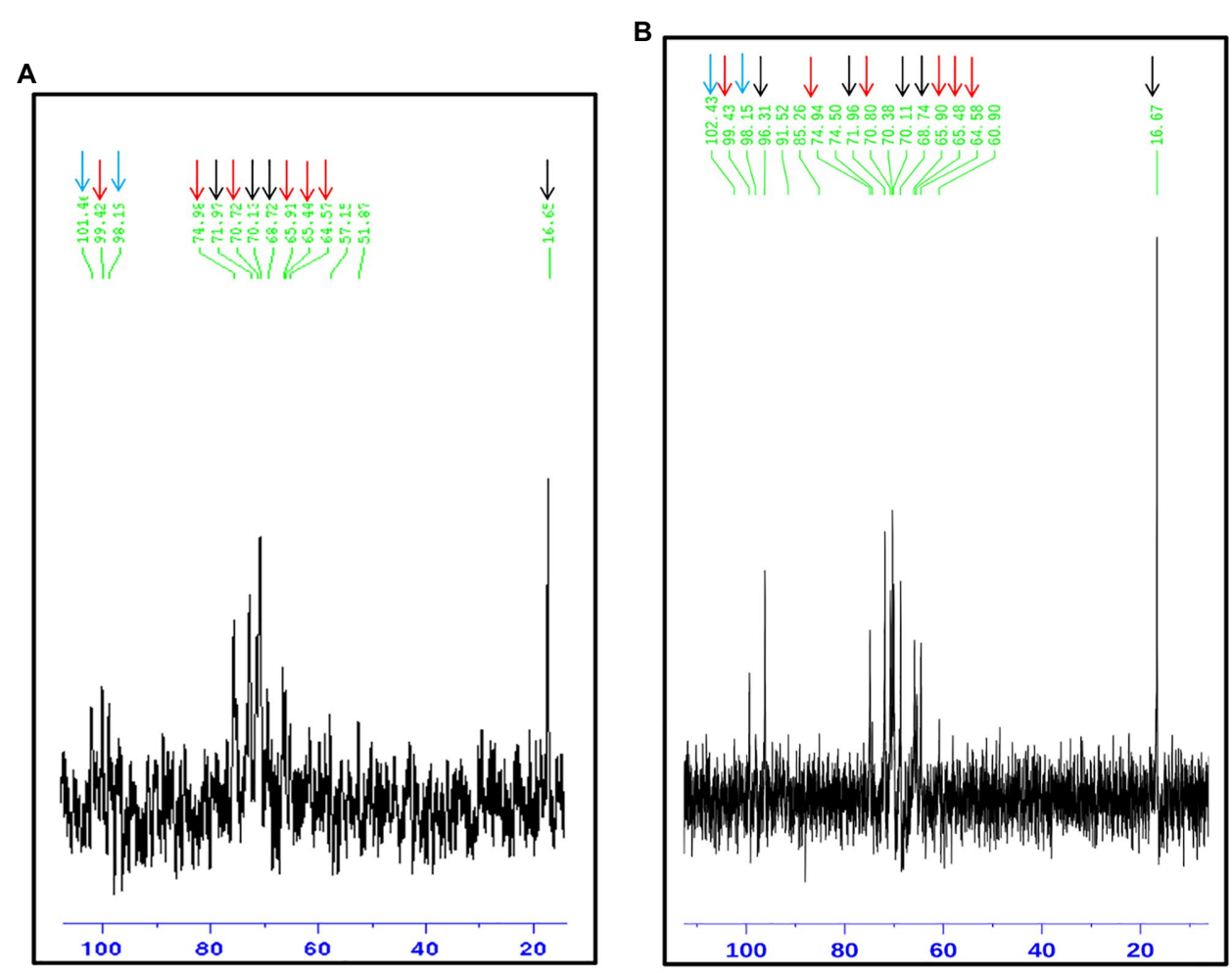

FIGURE 4 | ${ }^{13} \mathrm{C}-\mathrm{NMR}$ of the rhamnomannan fraction isolated from the strains presenting less virulence in yeast phase. Sporothrix schenckii 4822 (A) and S. brasiliensis 4824 (B) show the signals associated to type I rhamnomannan (red and black arrows), but also a signal corresponding to C-1 of $\alpha$-L-Rhap nonreducing end unit of $\alpha$-L-Rhap-(I, 2)- $\alpha$-Rhap and 2,4-di-0-substituted $\alpha$-D-mannopyranose units (Cian arrows; Travassos, 1985 ), which suggest longer side chains in the cell wall for these two strains. 
notoriously absent from the rhamnomannan of all the other strains (Figure 3D). The pattern of the ${ }^{13} \mathrm{C}-\mathrm{NMR}$ spectrum (Figure 2A) allowed us to determine how the rhamnose and mannan are linked in the rhamnomannan polymer. The rhamnomannan backbone is composed of mannose linked by $\alpha$-1,6-glycosidic bonds and single units of rhamnose as side chains, which has been reported as characteristic of rhamnomannans isolated at $37^{\circ} \mathrm{C}$ from the $\mathrm{S}$. schenckii yeast phase, first described as rhamnomannan type I (Figure 2A; Table 2; Travassos et al., 1973, 1974; Gorin et al., 1977). It is worth mentioning that the ${ }^{13} \mathrm{C}-\mathrm{NMR}$ spectra for the cell wall of S. schenckii, strain MYA4822, and S. brasiliensis MYA4824, showed unique signals at 98.15, 101.4, and $102.4 \mathrm{ppm}$, associated with the C-1 of $\alpha$-L-Rhap nonreducing end unit of $\alpha$-L-Rhap-(1,2)- $\alpha$-Rhap and 2,4-di-0-substituted $\alpha$-D-mannopyranose units, which suggest longer side chains in the cell wall rhamnomannan for these two strains when compared to the other strains under study (Figure 4).

\section{Polysaccharide Quantification in the Cell Wall Fractions}

For polysaccharide quantification, the fractions obtained by alkali and acid fractionation were further analyzed by colorimetric techniques as described in the methods section. Table 3 shows the relative cell wall polysaccharides content for $S$. schenckii and $S$. brasiliensis strains. The polysaccharide analysis for the cell walls of all strains in the yeast phase, showed a higher chitin content (around 27\%) for the two S. brasiliensis strains,

TABLE 3 | Cell wall polysaccharide content comparison of the $Y$ phase of the $S$. schenckii and S. brasiliensis strains under study.

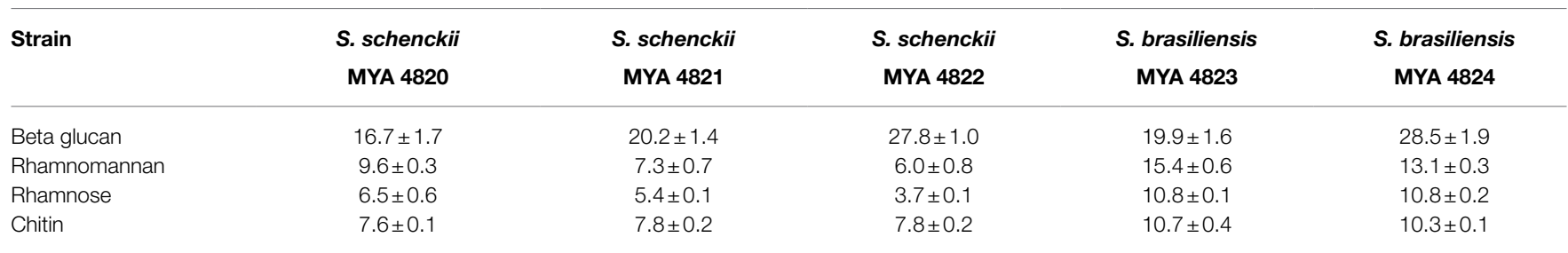

Tukey Honestly Significant Difference (HSD) post hoc test was used for intra and inter species comparative analyses. Value of $p<0.05$. Quantification of cell wall components were made by triplicate. SEM is shown.

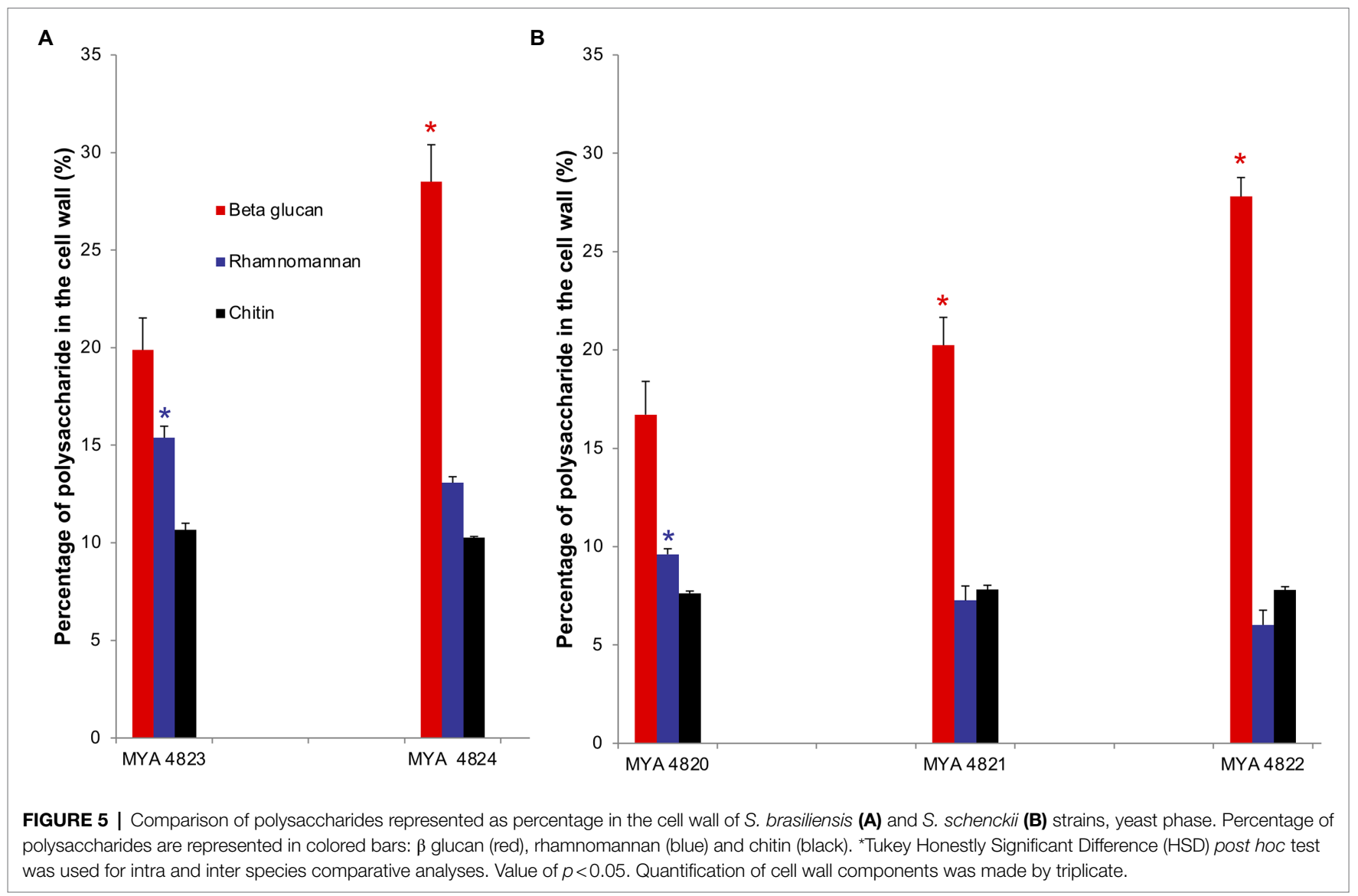


when compared to the S. schenckii strains (Table 3; Figure 5), as previously reported (Lopes-Bezerra et al., 2018). A difference was evident for the cell wall $\beta$-glucan relative content (around $28 \%$ more $\beta$-glucan) of the lower virulent S. schenckii MYA 4822 and $S$. brasiliensis MYA 4824 strains when compared to the higher virulent strains (Table 3; Figure 5). Rhamnomannan relative contents were higher for both $S$. brasiliensis strains analyzed, when compared to the $S$. schenckii strains (up to $38 \%$ more rhamnomannan). Also, a higher rhamnomannan relative content could be observed in the more virulent $S$. schenckii MYA 4820 strain, when compared with the non-virulent S. schenckii MYA 4822 strain (over 30\% higher; Table 3; Figure 5). The relationship between the level of virulence reported and the $\beta$-glucan/rhamnomannan cell wall ratio can be represented mathematically by an ascendant curve, with an $R^{2}=1$ for the polynomial function $y=0.0388 x^{4}-$ $0.3608 x^{3}+1.1913 x^{2}-1.1792 x+1.6$ (Figure 6), which shows an inverse relationship between the reported virulence and a higher ratio of cell wall $\beta$-glucans/rhamnomannan content.

Rhamnose residues from PRM are known to be the main antigenic epitopes found on the $S$. schenckii cell surface (Fernandes et al., 1999). Here, the rhamnose content in
S. brasiliensis strains was $40 \%$ higher compared to S. schenckii strains (Table 3). When comparing only the S. schenckii strains, the cell wall rhamnose content shows differences from high-to-low virulence for strains MYA 4820, MYA 4821, and MYA 4822 (Table 3; Figure 5). This observation fits the exponential curve: $y=14.722 \mathrm{e}^{-0.049 \mathrm{x}}$, with an $R^{2}=1$, that can be mathematically expressed as the linear equation: $\rho=-0.049(\beta)+2.7$, where $\beta$ represents the cell wall $\beta$-glucan content expressed as percentage and $\rho$ represent the $\operatorname{Ln}_{(\mathrm{Rha})}$, where Rha is the rhamnose cell wall content represented as a percentage (Figure 7). No significant differences were observed for the cell wall $\beta$-glucans among strains, except for S. schenckii MYA 4821, which had $20 \%$ more $\beta$-glucans than the rest of the analyzed strains.

\section{Chitin Exposure on the Yeast Cell Wall}

Chitin exposure on the cell wall for the five strains under study was determined in BHI-grown yeast cells. The highest chitin exposure on the cell wall was found for S. schenckii strain MYA 4822 (Figure 8), followed by S. schenckii strain MYA 4820. The lowest cell wall chitin exposure was observed for S. schenckii MYA 4821, and the two S. brasiliensis strains

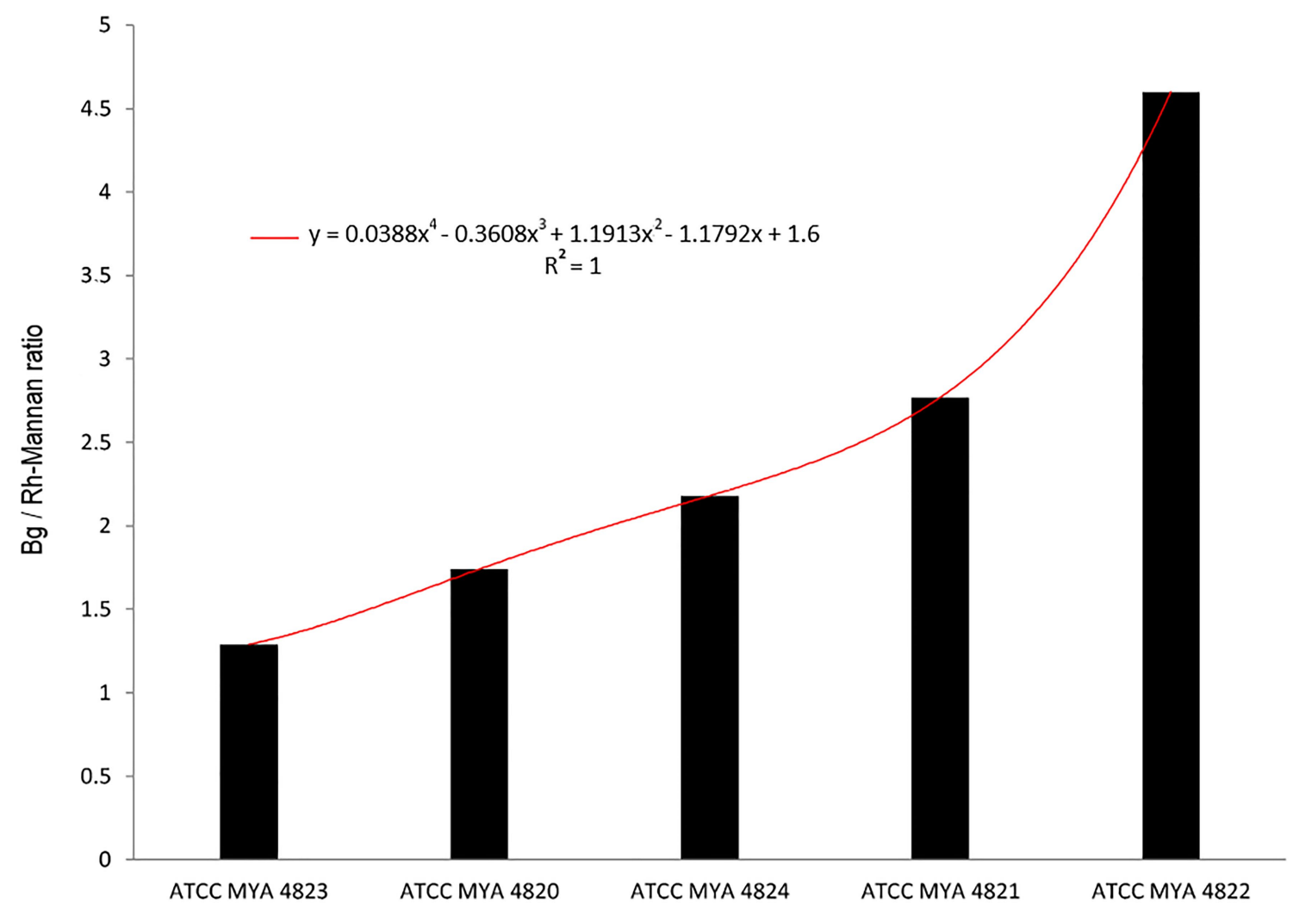

High-to-Low Virulence

FIGURE 6 | Relation between $\beta$ glucan vs. rhamnomannan ratio with strain virulence. Black columns represent the ratio of $\beta$ glucan to rhamnomannan present in the cell wall. Strains are arranged from higher to the lower virulence reported. The red curve represents the polynomial curve of relationship, mathematically represented by an ascendant curve with an $R^{2}=1$ with the polynomial function $y=0.0388 x^{4}-0.3608 x^{3}+1.1913 x^{2}-1.1792 x+1.6$. Bg, $\beta$-glucan; Rh-Mannan, rhamnomannan. 
MYA 4823 and MYA 4824, all of them reported as presenting higher virulence patterns (Nascimento et al., 2008; Castro et al., 2013).

\section{DISCUSSION}

The cell wall is the first point of contact with the host upon infection and colonization; understanding its composition allow unveiling specific mechanisms triggered by PAMPs and their corresponding PRRs (Gow et al., 2017). Recently, it was reported that carbon or nitrogen limitation during growth of yeast cells of $S$. brasiliensis and $S$. schenckii resulted in a reduced virulence, and the mechanism is related to affect the cell wall composition, where an increase in cell wall $\beta$-glucan, and a reduction of rhamnose and mannose was observed (LozoyaPérez et al., 2020). Also, the virulence-reduced strains showed a higher exposure of $\beta$-glucan, leading to an increase in the uptake of the fungus by hemocytes of Galleria mellonella (Lozoya-Pérez et al., 2020).

In the present work, we compared the cell relative composition of the polysaccharides of the pathogenic yeast morphotype of five Sporothrix strains, of which three were S. schenckii and two $S$. brasiliensis strains, with differences in virulence levels reported in a murine model (Table 1; Nascimento et al., 2008; Castro et al., 2013). To normalize the comparison, all the strains were grown under identical conditions in BHI broth, a widely used culture medium for Sporothrix spp. (Kong et al., 2006; Brito et al., 2007; Teixeira et al., 2009; Della Terra et al., 2017; De Almeida et al., 2018).

As previously reported, the main polysaccharides present in the cell wall of both $S$. schenckii and S. brasiliensis strains were: $\beta$-glucan, as major cell wall polysaccharide, followed by rhamnomannan and chitin (Table 3; Figure 5; Lopes-Bezerra et al., 2018; Lozoya-Pérez et al., 2020). A higher cell wall chitin content was observed in the cell wall of $S$. brasiliensis strains compared to $S$. schenckii strains, which also have been previously reported (Lopes-Bezerra et al., 2018). However, when comparing the cell wall polysaccharide composition of the five Sporothrix spp. strains, a pattern appeared to emerge, with higher $\beta$-glucans and lower rhamnomannan levels in cell wall contents present in the previously reported non-virulent or low virulent strains (S. schenckii MYA 4822 and MYA 4821 and S. brasiliensis MYA 4824). In contrast, lower $\beta$-glucan and higher rhamnomannan levels in cell wall content were shown in those strains for which higher virulence have been reported, regardless of the species (S. brasiliensis MYA 4823 and S. schenckii MYA 4820; Table 3; Figure 5). Therefore, the $\beta$-glucan/ rhamnomannan cell wall ratio can be mathematically represented by a polynomial function showing an inverse relationship to the virulence increase (Figure 6). Then, we focused on S. schenckii, for which we had strains with three different levels of virulence

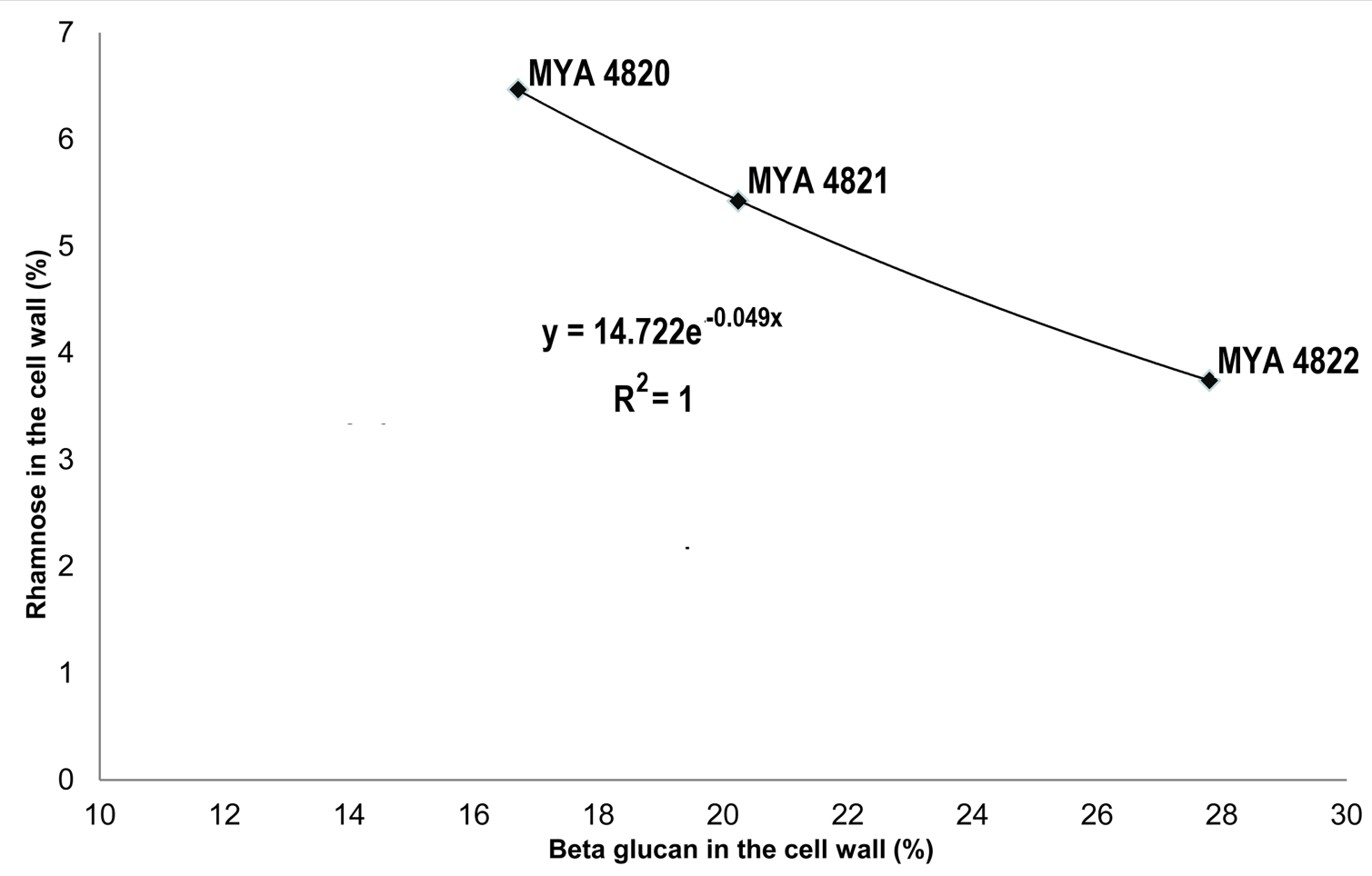

FIGURE 7 | A mathematical model for the Rhamnose/ $\beta$-glucan composition as expression of virulence. With an increase in reported virulence, the rhamnose proportion rise and $\beta$-glucan decreases. This observation fit to an exponential curve with an $R^{2}=1$, that could be expressed as a linear equation: $\rho=-0.049(\beta)+2.7$, where $\beta$ represents the $\beta$-glucan composition and $\rho=\mathrm{Ln}(\mathrm{Rha})$, where Rha is the rhamnose cell wall percentage. This model might be useful to predict the virulence level employing the $\beta$-glucan and rhamnose percentage ratio. This mathematical expression infers the highest rhamnose percentage to $15 \%(\beta=0)$ and for the lowest rhamnose percentage (1\%) $\beta=55.1 \%$. 
reported (Table 1) and noticed that cell wall rhamnose content increased, while the cell wall $\beta$-glucan content decreased when compared from the less to the highest reported virulence phenotype (Table 3; Figure 5). This observation can be mathematically expressed as a linear equation (Figure 7), which extrapolates the highest virulence for S. schenckii strains when the rhamnose percentage in the cell wall reaches $15 \%$ and the $\beta$-glucans cell wall content is $0 \%$, and the lowest virulence when the rhamnose percentage is $1 \%$ and the $\beta$-glucan content is $55.1 \%$ (intersection points on the $y$ and $x$ axis of the linear curve, respectively, Figure 7).

Recently, a bilayered cell wall model based on experimental data was proposed for $S$. schenckii and $S$. brasiliensis yeast cells (Lopes-Bezerra et al., 2018), which positioned the structural and more immunogenic chitin and $\beta$-glucans at the inner-most layer, and the PRM as an outermost layer covering the former.

The structural cell wall glycoconjugates, $\beta-1-3$ and $\beta-1-6-$ glucans, as well as chitin, are found in pathogenic fungal species as involved in the innate immune response as PAMPs, so the exposure of $\beta$-glucans and chitin on the fungal surface favors their binding to their corresponding PRRs presented on the host cells surface, allowing the uptake of the microorganism and/or triggering the secretion of specific cytokines (HernándezChávez et al., 2017). A Sporothrix spp. strain with a higher $\beta$-glucans/rhamnomannan ratio might favor the exposition of the immunogenic $\beta$-glucans to the host immune system, triggering its response before the infection can be established, therefore presenting a lower level of virulence. Indeed, Lozoya-Pérez et al. (2020) recently reported that a higher $\beta$-glucan exposure is in close relation with a lower virulence phenotype in Sporothrix spp. To determine whether chitin also might be playing a role in the differences in virulence levels, chitin exposition was measured in the Y pathogenic phase for the five Sporothrix strains. Only the non-virulent $S$. schenckii MYA 4822 presented a high chitin exposition on its cell surface under the growth conditions used in the present study (Figure 8), which together with the high $\beta$-glucans/rhamnomannan ratio, builds up evidence for the involvement in the non-virulence phenotype reported, and by triggering the host immune system more efficiently.

A conserved general structure of the cell wall polysaccharides for all Sporothrix strains in their yeast phase was evidenced by the IR spectra analyzed. However, some differences were observed when the rhamnomannans from the cell walls of the five Sporothrix strains were characterized by ${ }^{1} \mathrm{H}-\mathrm{NMR}$ and ${ }^{13} \mathrm{C}-\mathrm{NMR}$. Although a general pattern for both spectra was apparent for all the five strains studied (Figure 2), a closer inspection of the ${ }^{13} \mathrm{C}$-NMR spectra allowed us to identify unique signals for the cell wall rhamnomannan of the non-virulent and low virulent S. schenckii MYA 4822 and S. brasiliensis MYA 4824, respectively at $98.15,101.4$, and 102.4, associated

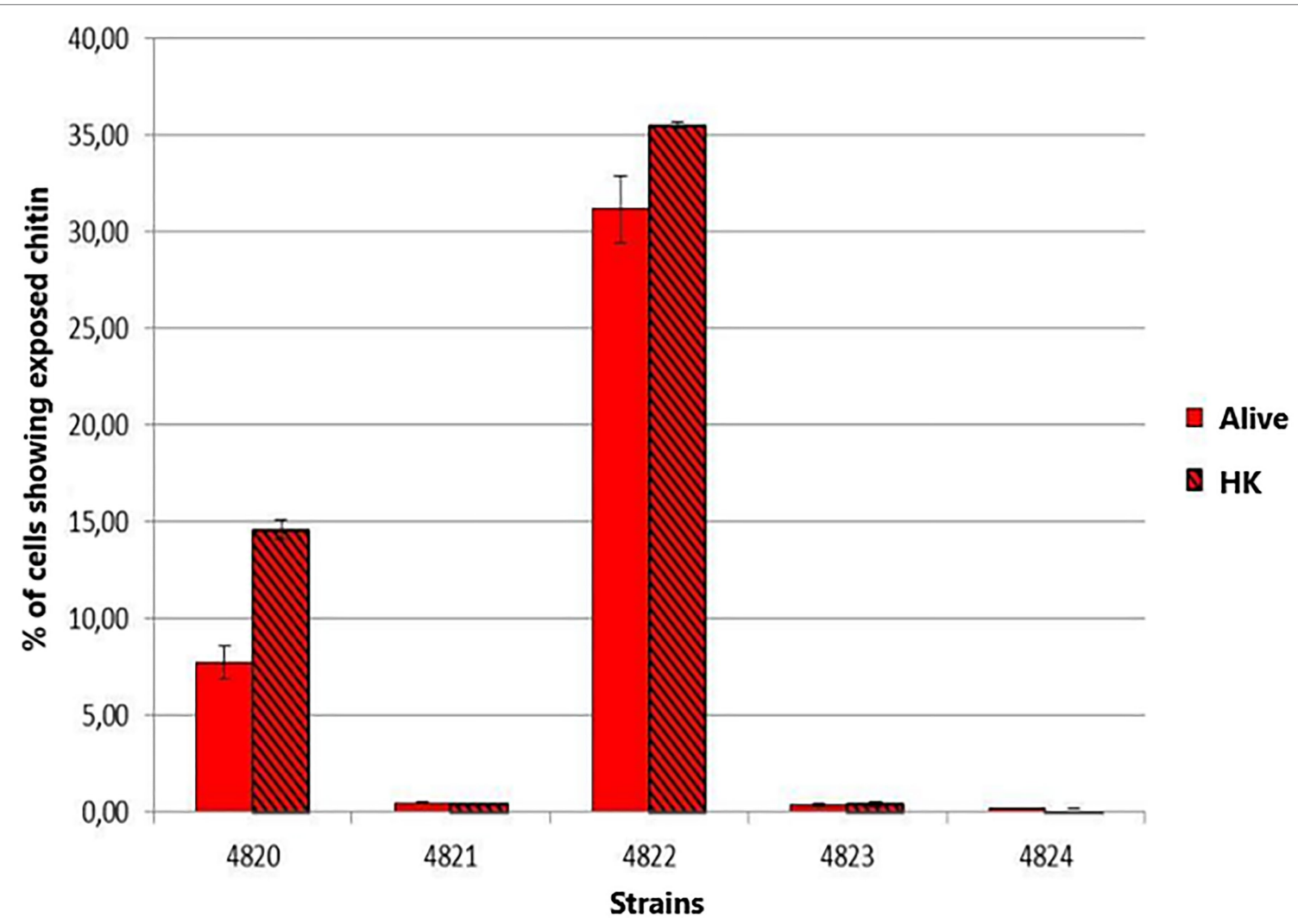

FIGURE 8 | Comparison of the chitin exposure on the yeast cells of S. schenckii and S. brasiliensis grown in Brain Heart Infusion (BHI) broth. The smooth bars represent the exposure of chitin under normal and live cell (Alive). The bars with frames represent the percentage of exposed chitin after the cells were heat inactivated $(\mathrm{HK})$. 
with the C- 1 of $\alpha$-L-Rhap non-reducing end unit of $\alpha$-L-Rhap(1,2)- $\alpha$-Rhap and 2,4-di-0-substituted $\alpha$-D-mannopyranose units, suggesting longer side chains in the cell wall rhamnomannan for these two strains. Methylation analyses of the rhamnomannan present in the reportedly least virulent strains and comparison with the higher virulent strains would provide further insight into such differences. Also, the comparison of the ${ }^{1} \mathrm{H}-\mathrm{NMR}$ spectra for the rhamnomannan of all the strains studied, confirmed a previous report, showing the presence of a $4.97 \mathrm{ppm}$ signal only for the $S$. brasiliensis MYA 4823, which has been reported as a high virulent strain (Castro et al., 2013). The analysis of virulent and non-virulent strains of the Sporothrix genus, suggests that the rhamnomannans of the cell wall determines the exposure of chitin and $\beta$-glucans, which ultimately triggers a strong immune response that explains the resulting virulence phenotype. To overcome the limitations of the present work and to either strengthen or discard the mathematical model of virulence here proposed, a broader study including more strains, testing their virulence in a single mathematical model of virulence for sporotrichosis, and exploring the alterations in cell wall composition from strains cultured in different media and their possible impacts on virulence would be necessary, and will definitely either reinforce or discard this model to assess virulence, specifically for the Sporthrix genus.

\section{REFERENCES}

Almeida-Paes, R., De Oliveira, L. C., Oliveira, M. M. E., Gutierrez-Galhardo, M. C., Nosanchuk, J. D., and Zancopé-Oliveira, R. M. (2015). Phenotypic characteristics associated with virulence of clinical isolates from the sporothrix complex. Biomed. Res. Int. 2015:212308. doi: 10.1155/2015/212308

Arrillaga-Moncrieff, I., Capilla, J., Mayayo, E., Marimon, R., Mariné, M., Gené, J., et al. (2009). Different virulence levels of the species of Sporothrix in a murine model. Clin. Microbiol. Infect. 15, 651-655. doi: 10.1111/j.1469-0691.2009.02824.x

Barros, M. B., de Almeida Paes, R., and Oliveira Schubach, A. (2011). Sporothrix schenckii and Sporotrichosis. Clin. Microbiol. Rev. 24, 633-654. doi: 10.1128/ CMR.00007-11

Brito, M. M. S., Conceição-Silva, F., Morgado, F. N., Raibolt, P. S., Schubach, A., Schubach, T. P., et al. (2007). Comparison of virulence of different Sporothrix schenckii clinical isolates using experimental murine model. Med. Mycol. 45, 721-729. doi: 10.1080/13693780701625131

Callens, S. F. J., Kitetele, F., Lukun, P., Lelo, P., Van Rie, A., Behets, F., et al. (2006). Pulmonary Sporothrix schenckii infection in a HIV positive child. J. Trop. Pediatr. 52, 144-146. doi: 10.1093/tropej/fmil01

Castro, R. A., Kubitschek-Barreira, P. H., Teixeira, P. A. C., Sanches, G. F., Teixeira, M. M., Quintella, L. P., et al. (2013). Differences in cell morphometry, cell wall topography and Gp70 expression correlate with the virulence of Sporothrix brasiliensis clinical isolates. PLoS One 8:e75656. doi: 10.1371/ journal.pone.0075656

Chakrabarti, A., Bonifaz, A., Gutierrez-Galhardo, M. C., Mochizuki, T., and Li, S. (2014). Global epidemiology of sporotrichosis. Med. Mycol. 53, 3-14. doi: $10.1093 / \mathrm{mmy} / \mathrm{myu} 062$

Clavijo-Giraldo, D. M., Matínez-Alvarez, J. A., Lopes-Bezerra, L. M., Ponce-Noyola, P., Franco, B., Almeida, R. S., et al. (2016). Analysis of Sporothrix schenckii sensu stricto and Sporothrix brasiliensis virulence in Galleria mellonella. J. Microbiol. Methods 122, 73-77. doi: 10.1016/j. mimet.2016.01.014

De Almeida, J. R. F., Jannuzzi, G. P., Kaihami, G. H., Breda, L. C. D., Ferreira, K. S., and De Almeida, S. R. (2018). An immunoproteomic approach revealing peptides from Sporothrix brasiliensis that induce a cellular immune response in subcutaneous sporotrichosis. Sci. Rep. 8:4192. doi: 10.1038/ s41598-018-22709-8

\section{DATA AVAILABILITY STATEMENT}

The original contributions presented in the study are included in the article/supplementary material, further inquiries can be directed to the corresponding author.

\section{AUTHOR CONTRIBUTIONS}

HV-D, LL-B, and GN-V conceived and designed the experiments. HV-D, LB, AA-A, BF, and NL-P performed the experiments. HV-D, GN-V, LL-B, and HM-M analyzed the data. HV-D and GN-V wrote the paper. All authors contributed to the article and approved the submitted version.

\section{FUNDING}

HV-D was supported by Instituto Venezolano de Investigaciones Cientificas, Venezuela (Project 112). GN-V was supported by CONACYT-Mexico (Ref. CF-2019-170701). HM-M was supported by CONACYT-Mexico (Ref. FC 2015-02-834). Flow cytometry analysis was supported by CONACYT (grants 3013205744 and 2019-300286).

de Beer, Z. W., Duong, T. A., and Wingfield, M. J. (2016). The divorce of Sporothrix and Ophiostoma: solution to a problematic relationship. Stud. Mycol. 83, 165-191. doi: 10.1016/j.simyco.2016.07.001

Della Terra, P. P., Rodrigues, A. M., Fernandes, G. F., Nishikaku, A. S., Burger, E., and de Camargo, Z. P. (2017). Exploring virulence and immunogenicity in the emerging pathogen Sporothrix brasiliensis. PLoS Negl. Trop. Dis. 11:e0005903. doi: 10.1371/journal.pntd.0005903

Dische, Z., and Shettles, L. B. (1948). A specific color reaction of methylpentoses and a spectrophotometric micromethod for their determination. J. Biol. Chem. 175, 595-603. doi: 10.1016/S0021-9258(18)57178-7

Erwig, L. P., and Gow, N. A. R. (2016). Interactions of fungal pathogens with phagocytes. Nat. Rev. Microbiol. 14, 163-176. doi: 10.1038/nrmicro.2015.21

Etchecopaz, A. N., Lanza, N., Toscanini, M. A., Devoto, T. B., Pola, S. J., Daneri, G. L., et al. (2020). Sporotrichosis caused by Sporothrix brasiliensis in Argentina: case report, molecular identification and in vitro susceptibility pattern to antifungal drugs. J. Mycol. Med. 30:100908. doi: 10.1016/j.mycmed.2019.100908

Fernandes, G. F., dos Santos, P. O., Rodrigues, A. M., Sasaki, A. A., Burger, E., and de Camargo, Z. P. (2013). Characterization of virulence profile, protein secretion and immunogenicity of different Sporothrix schenckii sensu stricto isolates compared with S. globosa and S. brasiliensis species. Virulence 4, 241-249. doi: 10.4161/viru.23112

Fernandes, K. S. S., Mathews, H. L., and Bezerra, L. M. L. (1999). Differences in virulence of Sporothrix schenckii conidia related to culture conditions and cellwall components. J. Med. Microbiol. 48, 195-203. doi: 10.1099/00222615-48-2-195

Gorin, P. A. J., Haskins, R. H., Travassos, L. R., and Mendonca-Previato, L. (1977). Further studies on the rhamnomannans and acidic rhamnomannans of Sporothrix schenckii and Ceratocystis stenoceras. Carbohydr. Res. 55, 21-33. doi: 10.1016/S0008-6215(00)84440-7

Gow, N. A. R., Gooday, G. W., Russell, J. D., and Wilson, M. J. (1987). Infrared and X-ray diffraction data on chitins of variable structure. Carbohydr. Res. $165,1-160$.

Gow, N. A. R., Latge, J., and Munro, C. A. (2017). The fungal cell wall: structure, biosynthesis, and function. Microbiol. Spectr. 5, 1-25. doi: 10.1128/ microbiolspec.FUNK-0035-2016

Hernández-Chávez, M. J., Pérez-García, L. A., Niño-Vega, G. A., and Mora-Montes, H. M. (2017). Fungal strategies to evade the host immune recognition. J. Fungi 3, 1-28. doi: 10.3390/jof3040051 
Klis, F. M., Boorsma, A., and De Groot, P. W. J. (2006). Cell wall construction in Saccharomyces cerevisiae. Yeast 23, 185-202. doi: 10.1002/yea.1349

Kong, X., Xiao, T., Lin, J., Wang, Y., and Chen, H. D. (2006). Relationships among genotypes, virulence and clinical forms of Sporothrix schenckii infection. Clin. Microbiol. Infect. 12, 1077-1081. doi: 10.1111/j.1469-0691.2006.01519.x

Latgé, J. P. (2007). The cell wall: a carbohydrate armour for the fungal cell. Mol. Microbiol. 66, 279-290. doi: 10.1111/j.1365-2958.2007.05872.x

Lopes-Alves, L. M., Mendonça-Previato, L., Fournet, B., Degand, P., and Previato, J. O. (1992). O-Glycosidically linked oligosaccharides from peptidorhamnomannans of Sporothrix schenckii. Glycoconj. J. 9, 75-81. doi: 10.1007/BF00731702

Lopes-Bezerra, L. M., Walker, L. A., Niño-Vega, G., Mora-Montes, H. M., Neves, G. W. P., Villalobos-Duno, H., et al. (2018). Cell walls of the dimorphic fungal pathogens Sporothrix schenckii and Sporothrix brasiliensis exhibit bilaminate structures and sloughing of extensive and intact layers. PLoS Negl. Trop. Dis. 12, 1-25. doi: 10.1371/journal.pntd.0006169

Lozoya-Pérez, N. E., Clavijo-Giraldo, D. M., Martínez-Duncker, I., García-Carnero, L. C., López-Ramírez, L. A., Niño-Vega, G. A., et al. (2020). Influences of the culturing media in the virulence and cell wall of Sporothrix schenckii, Sporothrix brasiliensis, and Sporothrix globosa. J. Fungi 6:323. doi: 10.3390/jof6040323

Nascimento, R. C., Espíndola, N. M., Castro, R. A., Teixeira, P. A. C., Penha, C. V. L., Lopes-Bezerra, L. M., et al. (2008). Passive immunization with monoclonal antibody against a $70-\mathrm{kDa}$ putative adhesin of Sporothrix schenckii induces protection in murine sporotrichosis. Eur. J. Immunol. 38, 3080-3089. doi: 10.1002/eji.200838513

Previato, J., Gorin, P., Haskins, R., and Travassos, L. (1979). Soluble and insoluble glucans from different cell types of the human pathogen Sporothrix schenckii. Exp. Mycol. 3, 92-105. doi: 10.1016/S0147-5975(79)80021-3

Rodríguez-Brito, S., Niño-Vega, G., and San-Blas, G. (2010). Caspofungin affects growth of Paracoccidioides brasiliensis in both morphological phases. Antimicrob. Agents Chemother. 54, 5391-5394. doi: 10.1128/AAC.00617-10

Rondle, C. J. M., and Morgan, W. T. J. (1955). The determination of glucosamine and galactosamine. Biochem. J. 61, 586-589. doi: 10.1042/bj0610586

Rossow, J. A., Queiroz-Telles, F., Caceres, D. H., Beer, K. D., Jackson, B. R., Pereira, J. G., et al. (2020). A one health approach to combatting Sporothrix brasiliensis: narrative review of an emerging zoonotic fungal pathogen in South America. J. Fungi 6, 1-27. doi: 10.3390/jof6040247

Ruiz-Herrera, J., Victoria Elorza, M., Valentín, E., and Sentandreu, R. (2006). Molecular organization of the cell wall of Candida albicans and its relation to pathogenicity. FEMS Yeast Res. 6, 14-29. doi: 10.1111/j.1567-1364.2005.00017.x

San-Blas, G., and San-Blas, F. (1994). "Preparation and analysis of purified cell walls of the mycelial and yeast phase of Paracoccidioides brasiliensis," in
Molecular Biology of Pathogenic Fungi: A Laboratory Manual. eds. B. Maresca and G. Kobayashi (New York: Telos Press), 489-498.

Synytsya, A., and Novak, M. (2014). Structural analysis of glucans. Ann. Transl. Med. 2, 1-14. doi: 10.3978/j.issn.2305-5839.2014.02.07

Teixeira, P. A. C., de Castro, R. A., Nascimento, R. C., Tronchin, G., Torres, A. P., Lazéra, M., et al. (2009). Cell surface expression of adhesins for fibronectin correlates with virulence in Sporothrix schenckii. Microbiology 155, 3730-3738. doi: $10.1099 / \mathrm{mic} .0 .029439-0$

Travassos, L. R. (1985). "Sporothrix schenckii," in Fungal Dimorphism. eds. P. J. Szaniszlo and J. L. Harris (New York, London: Plenum Press), 121-163.

Travassos, L. R., Gorin, P. A. J., and Lloyd, K. O. (1973). Comparison of the rhamnomannans from the human pathogen Sporothrix schenckii with those from the Ceratocystis species. Infect. Immun. 8, 685-693. doi: 10.1128/ iai.8.5.685-693.1973

Travassos, L. R., Gorin, P. A. J., and Lloyd, K. O. (1974). Discrimination between Sporothrix schenckii and Ceratocystis stenoceras rhamnomannans by proton and carbon-13 magnetic resonance spectroscopy. Infect. Immun. 9, 674-680. doi: 10.1128/iai.9.4.674-680.1974

Yemm, E. W., Cocking, E. C., and Ricketts, R. E. (1955). The determination of amino-acids with ninhydrin. Analyst 80, 209-214. doi: 10.1039/an9558000209

Zhang, Y., Hagen, F., Stielow, B., Rodrigues, A. M., Samerpitak, K., Zhou, X., et al. (2015). Phylogeography and evolutionary patterns in Sporothrix spanning more than 14000 human and animal case reports. Pers. Mol. Phylogeny Evol. Fungi 35, 1-20. doi: 10.3767/003158515X687416

Conflict of Interest: The authors declare that the research was conducted in the absence of any commercial or financial relationships that could be construed as a potential conflict of interest.

Publisher's Note: All claims expressed in this article are solely those of the authors and do not necessarily represent those of their affiliated organizations, or those of the publisher, the editors and the reviewers. Any product that may be evaluated in this article, or claim that may be made by its manufacturer, is not guaranteed or endorsed by the publisher.

Copyright (C) 2021 Villalobos-Duno, Barreto, Alvarez-Aular, Mora-Montes, LozoyaPérez, Franco, Lopes-Bezerra and Niño-Vega. This is an open-access article distributed under the terms of the Creative Commons Attribution License (CC BY). The use, distribution or reproduction in other forums is permitted, provided the original author(s) and the copyright owner(s) are credited and that the original publication in this journal is cited, in accordance with accepted academic practice. No use, distribution or reproduction is permitted which does not comply with these terms. 